\title{
A REVIEW OF THE GRASS SPECIES INTRODUCTIONS INTO THE TUSSOCK GRASSLANDS OF THE SOUTH ISLAND, NEW ZEALAND
}

\author{
J. A. Douglas \\ Ruakura A gricultural Research Centre, Private Bag, Hamilton
}

\section{INTRODUCTION}

THE EARLY SETTLERs and their stock moved into the inland South Island tussock grasslands in the 1850 s. It was an area of rich Pasture and the official estimate of the time (1857) was that the superior grasses could carry one sheep to two acres, good grasses one sheep to three acres, and inferior one sheep to four to five acres (Beettie, 1947).

One of the techniques used by the early runholders to provide fresh feed for stock was to burn the native grasses as soon as they were rank and dry enough to take fire. The folly of this was seen by Garvie (in Beattie, 1947) as early as 1858 and later Buchanan ( 1869) noted that "much of the grassland of Otago has been "thus deteriorated since its occupation, by fire; and it is no wonder that many of the runs require eight acres to feed one sheep according to an official estimate". This statement was later disputed by Petrie (1912) who stated that in the mid-seventies the majority of the sheepruns in Central Otago carried "one sheep to three acres or somewhat less".

At the stage in the mid-seventies when the depletion from burning was threatening rhe runholders seriously, the country was overrun by rabbits (Beattie, 1947). This brought about a critical situation in which the sheep carrying capacity was seriiously diminished without stocking rates being adequately reduced (Petrie, 1912). However it is important to note, as stated by Zctov (1938), "that the rabbit is not in itself a major agent of depletion, and that at least without the aid of sheep and especially fire it would not have exerted any significant influence on the vegetation". Nevertheless, the result of this added impetus to depletion was that some runholders abandoned their land in the 1880 s and others, such as Galloway Station near Alexandra (which in 1879 carried 75000 sheep on 129000 acres and in 190421 000) were forced to reduce stock numbers (Petrie, 
1912). In wetter regions such as the Waimakariri Basin where rabbits were not a problem, there was no appreciable change in carrying capacity over the same period (Cockayne, 1916).

With the spread of the settlers came the spread of the exotic flora both as intentional and unintentional introductions. As Thomson (1874) points out, the English seedsman was in the habit of reselling seed purchased from foreign importers as well as that harvested in Britain itself. Consequently seed imported from Britain to New Zealand was commonly a diverse mixture of good and bad from many countries and one recorded instance in Southland in 1869 was of a pasture mixture comprising 21 species together with 37 weed species (Thomson, 1874). The first attempt to sow "English" grasses in the Mackenzie Country was in 1859 (Burnett, 1927).

The early natural spread of the imported grasses was recorded by Armstrong (1871) in Canterbury and by Thomson (1874) and Kirk (1877) in Otago. Some grasses such as Yorkshire fog colcnized the tussock grasslands very quickly (Burnett, 1927). This superior colonizing ability of many of the imported grasses led to a replacement of many indigenous species and a gradual natural improvement of much of the tussock grasslands. Danthonia pilosa and Danthonia semi-annuluris colonized much of the North Canterbury and Marlborough hill country and elsewhere these and the adventives, browntop, Yorkshire fog, sweet vernal and Poa pratcnsis dominated the former native grasslands, particularly in the more humid areas (Sadd, 1920; Hilgendorf, 1935; Allan, 1936).

The purpose of this review has been to bring together the results and recommendations of grass introduction work in the tussock grasslands. It relates to published evidence and unpublishcd Ministry of Agriculture and Fisheries files but does not report unpublished research of the other agencies such as DSIR divisions, the universities or catchment boards. Grass' species names are largely presented as listed by the authors in the original publication. Today some names have changed and others are synonymous with grasses listed as different species but the lack cf detail in the initial descriptions has made it impossible to determine the modern nomenclature with certainty. Standard common names are used in the text where appropriate (N.Z. Weed and Pest Control Society, 1969). A list of the grass species introduced by the various research workers is given in the appendix, and the location of the major plant introduction sites in Fig. 1. 


\section{SOUTH ISLAND}

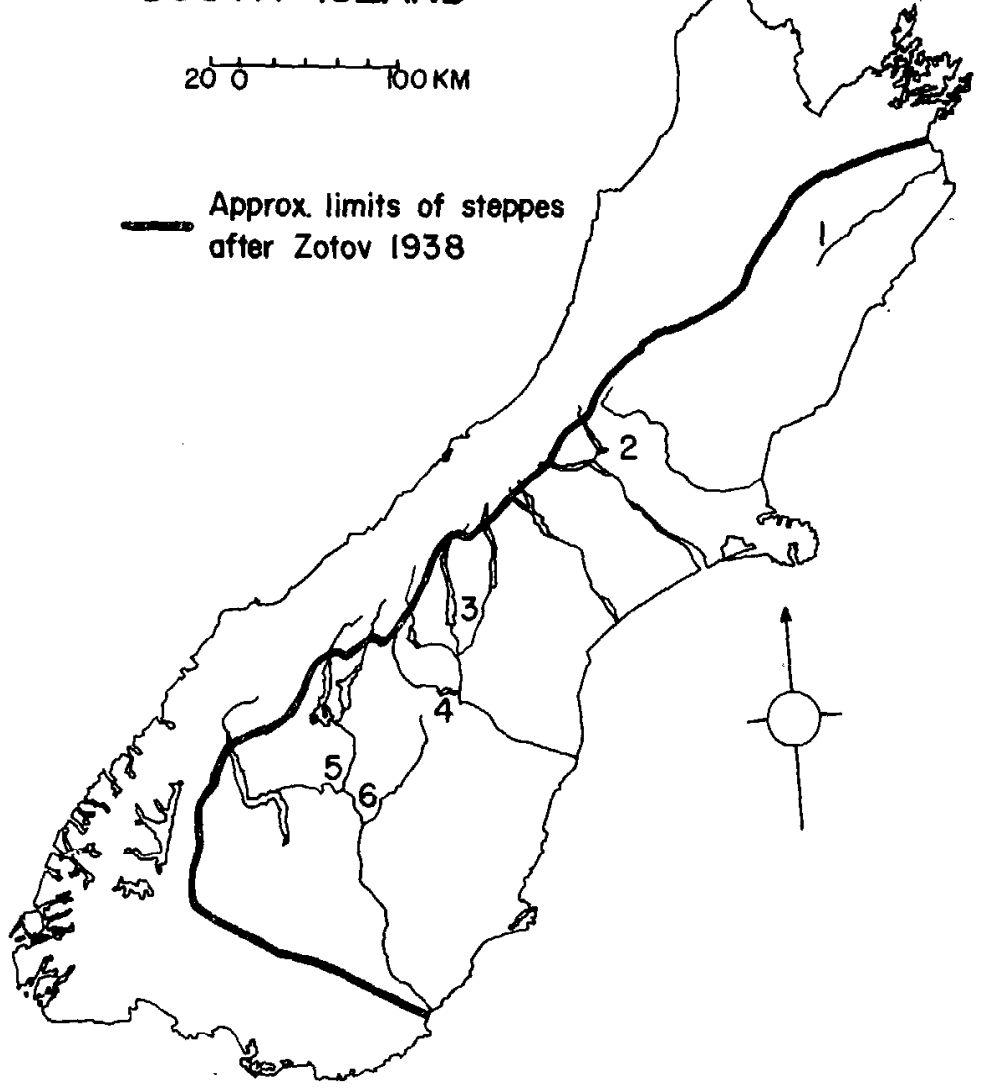

FIG. 1: The location of the major plant introduction sites in the South Island tussock grasslands.

(1) Molesworth. (2) Waimakariri Basin (Broken River). (3) Mackenzie Country. (4) Tara Hills High Country Research Station. (5) Pisa Flat (Cockayne Plots nearby). (6) Alexandra (Earnscleugh and Ophir areas).

\section{GRASS INTRODUCTIONS}

State action towards the rehabilitation of the tussock grasslands began in 1910 when trial areas were fenced and a total of 408 plot sowings made in the Mackenzie Country at Sawdon, Haldon and Simons Pass and in the Central Otago at Earnscleugh near Alexandra (Anon., 1910; Macphe.rson, 1911, 1912a, b, 1913). 
The grasses which showed the most promise in these trials were: tall oat grass, cocksfoot, prairie grass, A gropyron repens, Bromus inermis, Phalaris commufafa and Fesfuca dumeforum (Macpherson, 1913).

Ward (1923) extended the results of Macpherson's Haldoa plots to include areas unprotected from stock and rabbits. He had encouraging results on the dark faces with Yorkshire fog, cocksfoot, and perennial ryegrass, with tall fescue noticeable in a protected area. Later observations of the Macpherson and Ward plots were made by McGillivray ( 1929) who found cocksfoot, Poa pratensis and some ryegrass plants still doing well in the latter's plots. At Haldon and Simons Pass, cocksfoot, tall oat grass, Chewings fescue, browntop, Poa pratensis, Bromus inermis, Agrostis vulgaris and Festuca heferophylla were still present.

In the same period Agropyron pectinatum and European Festuca rubra were thought to be useful as these were spreading in the semi-arid regions (Cockayne, 191 1; Petrie, 1912; Taylor, 1914; Ward, 1923). In addition, Petrie (1912) suggested that stoloniferous grasses such as $\mathrm{P}$ oa pratensis and Agropyron repens and grasses from the arid areas of the United States and Australia such as Buchloe dactyloidcs, Agropyron glaucum, Boufeloua oligostachya and Themeda ciustralis may be worth while. Further suggestions were put forward by the Royal Commission of 1920 on the southern pastoral lands who suggested the most suitable grasses for surface sowing were: cocksfoot, danthonia, Yorkshire fog, Chewings fescue, Poa prafensis, Agrosfis stolonifera, A. vulgaris and Agropyron scabrum (Sadd, 1920).

Cockayne (1920a) also made use of Macpherson's plots when he conducted his palatability experiments at Earnscleugh. In reference to cocksfoot he concluded, "it now remains to discover the cheapest methods of establishing this splendid grass on the depleted hillsides". Cockayne (1922) considered that the objective of regrassing should be with species of high rather than low pasture value, a view also held by Zotov (1938). Cockayne established twelve plots on the depleted country near Cromwell in 1920 and 1921 (Cockayne, 1922). Cocksfoot, Chewings fescue, and tall fescue were the moist promising grasses in the unstocked plots (Tennent, 1935) but following a period of prolonged and severe grazing there was an 'abrupt change in grass dominance to tall oat grass, Poa pratensis and Chewings fescue (Douglas, 1970).

Little further trial work was reported prior to the Second World War apart from a recommendation from Wilkie (1939) 
that Agropyron cristatum would be a useful plant in Marlborough and Calder (1938) who suggested that tall oat grass could be used to replace the indigenous tussocks.

\section{The Soll Conservation Movement}

The passing of the Soil Conservation and Rivers Control Act in 1941 led to the beginning of an organization with staff and land reserves specifically to find ways of reducing soil erosion. The history of this movement and its work has been recorded by McCaskill (1973), and in relation to this paper it led to further widespread testing of grass species.

A large number of grass species and strains were tested in the semi-arid zone at the Tara Hills High Country Research Station and the Pisa Flat Experimental Area near Cromwell. At Tera Hills in the 1950 s research was directed towards soil conservatioa. Grasses were tested under severe grazing regimes and those which proved promising were: Bromus inermis, B. popovii, Agropyron intermedium, Eragrostis curvula, Dactylis woronowii, phalaris, tall fescue and tall oat grass (Soil Con. and Rivers Control Council, 1956, 1957) .

In a later inspection of these plots, all the aforementioned grasses persisted with the exception of Bromus popovii (Dunbar and Douglas, unpubl., 1964). In the grazing nursery rows, cocksfoot, Dactylis woronowii, A gropyron smithii, A. elongatum, Brachypodium pinnatum, B. phoenicoides, tall fescue, Chewings fescue, browntop, and Poa pratensis had survived. Of the 45 species in the field sowings, cocksfoot, Dactylis woronowii, Agropyron elongatum, A. intermedium and A. obtusiusculum were given the highest productive ratings.

More recent research at Tara Hills has shown that cocksfoot and tall fescue were higher producing than perennial ryegrass, phalaris, prairie grass and Bromus marginatus when each was planted in asscciation with lucerne (Douglas and Kinder, 1973).

At Pise Flat, Calder (1944) considered tall oat grass, cocksfoot, danthonia, Chewings fescue, browntop, Poa pratensis, Agropyron scabrum, and A. cristatum showed the most promise. A later report by Lunn ( 195 1) indicated that all these grasses except browntop and Agropyron cristatum but with the addition of phalaris and tall fescue, dominated the field sowings under a simulated winter run country stock management system.

The trials in Central Otago were extended from Pisa Flat to several other sites throughout the district (Saxby, 1957). From 
this work cocksfoot, tall oat grass, Bromus inermis and B. marginatus appeared promising (Saxby, 1957). The last report of the nursery and experimental areas of Central Otago was by Ludecke (1962) who suggested cocksfoot, tall oat grass, tall fescue, Dactylis woronowii and Bromus inermis were the most promising grasses.

In 1944 Botany Division, DSIR, staff began nursery trials on a range of grasses at Molesworth from which the most promising species were considered to be Agropyron cristatum, A. elongatum, A. intermedium, Bromus inermis and Dactylis woronowii (Moore and Simpson, 1961). However, the authors noted that with the success being achieved with the oversowing of cocksfoot there was a waning interest in the less familiar grasses. Tall oat grass was also successful in the nursery sowing but it proved unpalatable to stock and later observations suggested that it could become a serious weed (McCaskill, 1970).

More recently research has been directed towards the regrassing of the high altitude erosion slopes. Fertilizers have been shown to be essential (O'Connor and Lambrechtsen, 1967; Dunbar, 1970a, b, 1971). Dunbar (1971) achieved a quicker plant cover using exotic species, particularly Yorkshire fog rather than native tussock species (Dunbar, 1970a) and O'Connor and Lambrechtsen (1967) showed that there were wide cultivar variations within. a species in their reaction1 to frost heaving. For instance, the cocksfoot cultivar 'Grasslands Apanui' was considerably more resistant to frost heaving than the Australian winter active cultivar 'Currie'.

\section{Agricultural Development}

In the 1950 s in the more humid regions of the tussock grasslands there was a change in emphasis from conservation to productive potential of land which 'already had a covering of browntop, Yorkshire fog, and sweet vernal. However, the earliest trials in the Waimakariri basin were sown without fertilizer and only inter-row cultivation of the plant nursery kept out the competitive adventive species.

In row trials at Craigieburn Station, Sewell ( 1952) found Agropyron intermedium, A. dasystachyum, A. scabrum, Bromus carinatus, and cocksfoot gave the best performance of the grasses he tested. Sowings into cultivated ground showed that these promising introductions were slower to establish than the native Agropyron scabrum and cocksfoot. In an unpublished report on 
these studies, L. D. Bascand (1958, unpubl.) indicated that, at the completion of this research, cocksfoot, Dactylis woronowii, Bromus marginatus, B. popovii, Fesfuca elatior, Agropyron intermedium and the Roxburgh and Alexandra ecotypes of Agropyron scabrum were the most promising. Earlier, in addition to these species, Bromus carinatus, Elymus glaucus and Fesfuca maieri were considered promising (Bascand, unpubl.) .

Promising species from the Craigieburn nurseries were also sown in the Riversdale 'area on to both ploughed and pitchpole harrowed ground but the only species to compete successfully against the reinfestation of browntep and creeping fog were cocksfoot and tall oat grass (Basoend, 1955, unpubl.).

Dingwall (1955) noted that it was difficult to establish grasses by oversowing grassland invaded by browntop and sweet vernal but he suggested that in good conditions cocksfoot and tall oat grass could often be established. Further research at Broken River on species evaluation by sod-seeding (Dingwall, 1956) also failed because of the inability of the sown species to compete with the resident browntop dominated sward.

Bascand (unpubl., 1956) in conjunction with Dr M. R. Love (University of California) found cocksfoot, Phalaris coierulescens, tall oat grass, Danthonia californica and Bromus inermis to be the most promising of 17 species, 4 months after sowing. Two Poa species three Oryzopsis species, and Festuca idahoensis used in the sowings showed poor establishment and growth.

O'Connor (1959) tested 65 species and strains of grasses with fertilizer additions. The outstanding species on tiller and leaf length rankings were Agropyron scabrum, Bromus popovii, perennial ryegrass, cocksfoot and Yorkshire fog.

The Holbrook trials in the Mackenzie Country were overdrilled into the tussock sward by L. W. Blackmore in 1948 and later reviewed by Sievwright (1956). Cocksfoot proved the most successful grass, with tall oat grass and tall fescue also prominent. Agropyron cristatum established in bare areas and while persistent it made only limited growth. Earlier unpublished reports suggested Agropyron intermedium was also worth while.

Results obtained by Sievwright (unpubl., 1957) at Mt. Hay Station, Tekapo, from plots sown in 1952 indicated cocksfoot and Poa pratensis were the best grasses, with Bromus inermis and tall fescue also worth while. Sweet vernal, Danfhonia pilosa and Eragrostis curvula produced well but were not readily eaten by sheep. Elymus glaucus, Agropyron intermedium and A. elongatum were considered only fair in production and palatability. Earlier 
reports by Sievwright indicated that Elymus glaucus was the most promising North American species under test but it was almost eliminated by the continuous set-stocking of the plots.

\section{Observations on Species palatability}

The earliest reports on the palatability of some of the introduced grasses were made. by Cockayne (1920b, 1920c) who made observations of sheep grazing at Earnscleugh. Cocksfoot was considered to be highly palatable, and Poa pratensis, Yorkshire fog, Chewings fescue and tall fescue of medium palatability. Cockayne suggested perennial ryegrass, sweet vernal, tall oat grass, A grostis vulgaris, Pkicilaris commutata, P. bulbosa and Agropyron scabrum were of low palatability under the existing conditions.

Little further attentioa has been paid to the palatability of the introduced species. Moore and Simpson (1961) and Douglas (1970) also reported the low palatability of tall oat grass, Saxby (1957) reported the low palatability of Eragrostis curvula, and Lunn ( 195 1) that of Brachypodium phoenicoides. Unpublished results of Sievwright (1 957) from his Mt Hay experiments suggested sweet vernal, Danthonia pilosa and Ercigrostis curvula were not readily eaten by sheep.

More recently Douglas and Drew (1969) have drawn attention to the low feeding value of frosted cocksfoot, and Vartha and Clifford ( 1971) have shown that, while Yorkshire fog and perennial ryegrass gave superior growth, cocksfcot and tall fescue were of greater value for winter feed because they did not decompose as quickly as the 'former species when frosted.

Saxby (1950) suggested that the grass species most suitable for the tussock grassland conditions were tall oat grass, cocksfoot, phalaris, tall fescue, danthonia, Poa pratensis, Agropyron scabrum, and Brachypodium phoenicaides. Further reports by Hercus (1954), Thornton (1954) and Maclean (1957) recommended cocksfoot, tall oat grass and Bramus inermis. In addition, Hercus also recommended danthonia, and Thornton, tall fescue, Agropyron intermedium, Elymus glaucus and Eragrostis curvula.

O'Connor (1960) suggested that for general purposes in the immediate future Agropyron scabrum, browntop, sweet vernal, Yorkshire fog, cocksfoot, tall oat grass, tall fescue and ryegrass would be the most valuable under conditions of improved fertility. He found no other native or exotic. grasses he had tested were capable of high production under improved fertility conditions. 
At a seminar on grass introduction into the tussock grasslands it was suggested that further research, be conducted on the following species (Anon., 1964) :

(a) Semi-arid zone; new strains of cocksfoot, tall oat grass, tall fescue and some species of Agropyron.

(b) Sub-humid zone; Agropyron sp. and Chilean sp. of Festuca and Deschampsia and strains of tall fescue and Bromus sp.

(c) Humid zone; new strains of tall oat grass.

For aerial oversowing of the tussock grasslands, cocksfoot has become the major recommendation (Douglas, 1966). It has been advocated for the semi-arid, the sub-humid; and large areas of the humid zone of the tussock grasslands (Anon., 1964).

\section{DISCUSSION AND CONCLUSIONS}

In 'excess of 150 different grass species of 50 different genera have been sown in trials in the tussock grasslands, the results and recommendations of which must be considered in relation to the overall changes in the region.

The degradation of the tussock grasslands by burning, overstocking and rabbits began with the settlers. The indiscriminate burning was denounced by Buchanan (1869) and Cockayne (1910) and although burning became more confined to autumn and spring periods (Cockayne, 1916), control did not come until the Soil Conservation Act of 1941 led to the establishment of catchment boards and the requirement of a permit to burn (McCaskill, 1973). Controll of r\&bits was not put on a sound basis until the introduction of the "killer" policy in 1947 (Howard, 1959). In addition, application of fertilizer to the South Island range country became practical only with the advent of aerial topdressing and the high wool prices of the early 1950s gave incentive for improvement. Concomitant with the use of fertilizers came the swing to legumes rather than grasses for surface sowing, with the adventive grasses browntop, Yorkshire fog, sweet vernal and Poa pratensis completing the sward.

Thus the 1950s were the turning point in the pastoral use of the tussock grasslands. The discipline of productive capability of the land replaced that of soil conservation and an era of spectacular improvement began.

With these dramatic changes many of the earlier grass species recommendations no longer relate to the improved conditions 
since the productive potential of the grasses was never measured nor suitable fertilizers added so they could Fully express their potential. In addition, many species failed to establish, and overall the failure of a grass in these earlier trials cannot be taken as implying the species would not be useful in the environment.

Plant growth in the semi-arid zone is governed more by climatic conditions than soil fertility as it is in the humid regions and because of this the earlier trials without fertilizer tend to give a more accurate picture in this former zone. Consequently, the species recommendations fcr Central Otago and the drier regions of the Mackenzie Country could be looked upon as a reasonable guide. Cocksfoot (Dactylis glomerata) is already the most important grass in this region, this being well founded in the earlier trials, and further research to evaluate the productive potential of a range of its cultivars and other Dactylis species appears worth while. In addition, the selection of a more palatable tall oat grass would be beneficial because of the ease with which thi species establishes and further investigations of the potential of tall fescue and some Bromus species such as Bromus inermis need to be considered.

In the humid zone of the tussock grasslands the results of the research appear of little value at least until fertilizers were used in species evaluation (Dingwall, 1956; O'Connor, 195y). Given adequate fertilizer, one could expect the reaction of species in the humid tussock grasslands to be similar to those on the developed humid coastal plains and downlands. This is borne out by O'Connor (1959) who showed that the downland species of ryegrass, cocksfoot and Yorkshire fog were amongst the most highly rated grasses when fertilizer was applied. It was further amplified by O'Connor in 1961 (1961a, b, c) who showed the dominant limiting factor to high production in the humid tussock grasslands was a lack of fertilizer. Consequently there appears little need to continue species evaluation research in the humid regions of the tussock grasslands except for specific purposes.

Overall, the improvements in the tussack grasslands have led to considerably increased production but this has mainly been confined to the spring-summer period and as a consequence the gap between summer and winter feed availability has widened. O'Connor (1961a) and Douglas (1966) both suggested a need for further research on cool season active species and Douglas and Drew (1969) have drawn 'attention to the low feeding value of frosted cocksfoot and suggested an investigatioe of grasses with high nutritive value as foggage was needed. 
Perhaps the most striking 'aspect of this review is the lack of production data which exists for individual species growing in the tussock grasslands environment. (Production figures: swards - O'Connor, 1959, 1960,1961a; four grasses - Vartha and Clifford, 1971; lucerne/grass mixtures - Douglas and Kinder, 1973.) In addition, it is worth while reflecting that, even after considerable trial work and the introduction of numerous grasses, the dominant introduced species throughout the tussock grasslands region are the self-spreading naturalized grasses, browntop, Yorkshire fog, sweet vernal and Poa pratensis, and the two main agricultural specie's of New Zealand, perennial ryegrass and cocksfoot. For stock numbers to rise and equate more closely with the feed produced, there is a pressing need to know how much feed a species produces, when it is produced, and whether overall production can be increased by changing from one grass species to another. Without this long overdue information the environment cannot be used efficiently.

\section{REFERENCES}

Allan, H. H., 1936: N.Z. Dept. sci. industr. Res. Bull., 49: 159 pp.

Anon., 1910: N.Z. Il Agric., 1: 477.

1964: Tussock Grasslds \& M ountain Lands Inst. Rev., 7: 25.

Armstrong, J. F., 1871: Trans. Proc., N.Z. Inst., 4: 309.

Beattie, Herries, 1947: Early Runholding in Otago. Otago Daily Times,

$$
\text { Dunedin. }
$$

Buchanan, J., 1869: Trans. Proc., N.Z. Inst., 1.

Burnett, T. D., 1927: In N atural $H$ istory of Canterbury (ed. Speight, Wall and Laing), Simpson and Williams, Christchurch. 299 pp.

Calder, G. G., 1938: N.Z. Il A gric., 57: 399. 1944: ibid., 68: 185.

Cockayne, A. H., 1910: ibid., 1: 7.

1911: ibid., 3: 1 .

1916: Trans. Proc., N .Z. Inst., 48: 154.

Cockayne, L., 1920a: N.Z. Ill A gric., 20: 82.

1920b: ibid., 21: 176

1920c: ibid., 21: 324.

1922: ibid. 25.129.

Dingwall, A. R., 1955: ibid., 91: 553. 1956: ibid., 93: 277.

Douglas, J. A., 1966: Proc. N.Z. Grassld Ass., 28: 86. 1970: Proc. N.Z. Ecol. Soc., 17: 18.

Douglas, J. A.; Drew, K. R., 1969: N.Z. agric. Sci., 4 (2): 23.

Douglas, J. A.; Kinder, J. W., 1973: N.Z. $/ l$ exp. A gric., 1: 23.

Dunbar, G. A., 1970a: Proc. N.Z. Ecol. Soc., 17: 25.

1970b: Tussock Grasslds \& M ountain Lands Inst. Rev., IS: 16. 1971: Proc. N.Z. Ecol. Soc., 18: 48.

Hercus, J. M., 1954: N.Z. Il Agric., 89: 263.

Hilgendorf, F. W., 1935: N.Z. D ept. sci. industr. Res., 47: 24 pp. 
Howard, W. E., 1959: N.Z. Dept. sci. industr. Res. Ser., 16. 47 pp.

Kirk, T., 1877: Trans. Proc., N.Z. Inst., 10: 406.

Ludecke, T. E., 1962: N.Z. Il Agric., 104: 168.

Lunn, W. A., 1951: ibid., 83: 363.

McCaskill, L. W., 1970: Moleswortk, Reed, Wellington. $292 \mathrm{pp}$. 1973: Hold this Land, Reed, Wellington. $274 \mathrm{pp.}$

McGillivray, R., 1929: N.Z. Il Agric., 39: 73.

Maclean, S. M., 1957: ibid., 95: 19.

Macpherson, A., 1911: ibid., 3: 391. 1912a: ibid., 4: 21.

1912b: ibid., 4: 308.

1913: ibid., 7: 387.

Moore, L. B.; Simpson, M. I. A., 1961: N.Z. Il agric. Res., 4: 83.

N.Z. Weed and Pest Control Society, 1969: Standard Common Names for Weeds in N.Z. Editorial Services, Wellington.

O’Connor, K. F., 1959: Proc. N.Z. Inst. Agric. Sci., 5: 86.

1960: Proc. Lincoln Col. Fmrs Conf., 10: 82.

1961a: N.Z. Il agric. Res 4: 686.

1961b: ibid., 4: 698.

1961c: ibid., 4: 709.

O'Connor, K. F.; Lambrechtsen, N. C., 1967: Proc, N.Z. Ecol. Soc. 14: 1.

Petrie, D., 1912: N.Z. Dept Agric. Ind. \& Comm. Bull., 23 (n.s.). 16 pp.

Sadd, R. D., 1920: Southern Pastoral Lands. Report of Commission.

Government Printer, Wellington. $24 \mathrm{pp}$.

Saxby, S. H., 1950: Proc. N.z. Grassld Ass., 12: 4.4.

1957: N.Z. Il Agric., 95: 238.

Sewell, T. G., 1952: Proc. N.z. Grassld Ass., 14: 123.

Sievwright, H. M., 1956: N.Z. Il Agric.. 92: 122.

Soil Conservation and Rivers Control Council, 1956: Annual Report 1956, 14: 15. 1957: Annual Report 1957, 15: 18.

Taylor, S. M., 1914: N.Z /l Agric., 8: 169.

Tennent, R. B., 1935: Proc. N.Z. Grassld Ass., 4: 1.

Thomson, G. M., 1874: Trans. Proc. N.Z. Inst., 7: 370.

Thornton, F. H., 1954: N.Z. Il Agric., 89: 65.

Vartha, E. W.; Clifford, P. T.. 1971: Tussock Grasslds \& Mountain Lands Inst. Rev., 22: 55.

Ward, F. E., 1923: N.Z. Jl Agric., 26: 358.

Wilkie, D. R.. 1939: ibid., 59: 43.

Zotov, V. D., 1938: N.Z. Il Sci. Technol., 20A: 212.

\section{APPENDIX}

\section{Grass Species Sown in some Plant Introduction Trials} in Tussock Grasslands

Eaoh grass has been named as it was given in the original work. Today some names have changed and others are synonymous with grasses given in the list as different species.

Key

Each number given below identifies the trial reference and when referred to the list gives the species sown by the particular officer or at that particular research station. 
(1) Cockayne, L. (1922), Douglas, J. A. (1970).

(2) Macpherson, A. (1912a, b), Anon. (1910).

(3) Moore, L. B., Simpson, M. J. A. (1961).

(4) O'Connor, K. F. (1950s), unpubl. Dept. of Agriculture files.

(5) Pisa Flat Experimental Area (1940s), unpubl. Dept. of Agriculture tiles.

(6) Sievwright, H. M. (1956), unpublished tiles.

(7) Sewell, T. G. (1950), unpubl. Dept. of Agriculture files.

(8) Tara Hills Research Station (1940-50), unpubl. Dept. of Agriculture files.

(9) Ward, F. E. (1923)

(10) Ophir Experimental Area (1950s), unpubl. Dept. of Agrioulture files.

(i1) Bascand, L. D. (1950s), unpublished files.

(12) Dingwall, A. R. (1956).

*Denotes failed to establish.

\section{Lisf}

Agropyron caninurn

A. ciliare

A. crisfatum

A. dasystachyum

A. desertorum

A. elongatum

A. glaucum

A. inerme

A. intermedium

A. kirkii

A. obtusiusculum

A. pauciflorum

A. pectinatum

A. riparium

A. repens

A. rigidum

A. scabrum

A. scabrifolium

A. semicosfatum

A. sibiricum

A. srnithii

A. spicatum

A. trachycaulum

A. trichophorum

Agrostis alba

A. castellana

A. gigantea

A. stolonifera

A. tenuis

Aira caespitosa

Alopecurus pratcnsis

Andropogon furcatus

A. gerardi
$5^{*}$

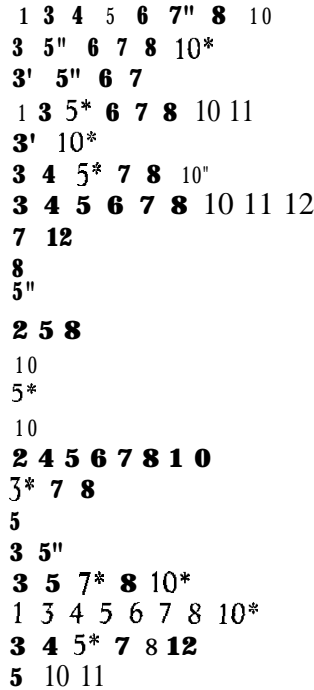




\begin{tabular}{|c|c|}
\hline & \\
\hline A. hallii & $510^{\prime}$ \\
\hline A. intermedius & $5^{*} 10^{*}$ \\
\hline A. ischaemum & $588^{\prime} 10^{\prime \prime}$ \\
\hline A. saccharoides & 5 \\
\hline A. scoparius & $58^{*}$ \\
\hline A. suparimo & $5^{*}$ \\
\hline A. tricharoides & 5 \\
\hline Anthoxanthum odoratum & 246 \\
\hline Aristida uniplumis & $8^{*}$ \\
\hline Arrhenathcrum elatius & 12345689101112 \\
\hline A. elatius var. bulbosum & 5 \\
\hline A. erianthum & 8 \\
\hline Bouteloua curtipendula & $235 " 10 ”$ \\
\hline B. eriopoda & $5^{*}$ \\
\hline B. filiformis & $8^{*}$ \\
\hline B. gracilis & $1357^{*} 810^{*}$ \\
\hline B. oligostachya & \\
\hline Brachypodium phoenicoides & 5810 \\
\hline B. pinnatum & 8 \\
\hline B. pinnatum var. glabrum & \\
\hline Bromus breviaristatus & 6 \\
\hline B. carinatus & 345678 \\
\hline B. catharticus & 245 \\
\hline B. coloratus & 4810 \\
\hline B. inermis & 123456781011 \\
\hline B. marginatus & 3478101112 \\
\hline B. maritimus & 37 \\
\hline B. mollis & 410 \\
\hline $\begin{array}{c}\text { B. popovii (probably B. sitchensis, } \\
\text { M. B. Forde, pers. comm.) }\end{array}$ & $\begin{array}{lllll}4 & 7 & 8 & 10 & 12\end{array}$ \\
\hline Buchloe dactyloides & $2^{*} \quad 3 \quad 5^{*} 7^{*} \quad 8 \quad 10^{*}$ \\
\hline Chaetochloa cuudata & 2 \\
\hline Chionochloa rigida & 8 \\
\hline Chloris cucullata & $5^{*}$ \\
\hline C. gayana & $25^{*}$ \\
\hline Cottea pappophoroides & $5^{*}$ \\
\hline Cynodon plectosiachyus & $5^{*}$ \\
\hline Cynosurus cristatus & 124567 \\
\hline Dactylis glomerata & 12456789101112 \\
\hline D. woronowii & $\begin{array}{lllll}3 & 7 & 8 & 10 & 12\end{array}$ \\
\hline Danthonia californica & 11 \\
\hline D. kirkii & 7 \\
\hline D. pilosa & $12 * 5681012$ \\
\hline D. semiannularis & 2 \\
\hline Deschampsia caespitosa & 7 \\
\hline Deyeuxia avenoides & 78 \\
\hline D. jorsteri & 8 \\
\hline Dichelachne crinita & 47810 \\
\hline Ehrharta calycina & $35 * 678$ \\
\hline Elymus augustus & $10^{*}$ \\
\hline E. canadensis & $356710^{*}$ \\
\hline E. giganteus & $810^{*}$ \\
\hline E. glaucus & 3567810 \\
\hline
\end{tabular}




\begin{tabular}{|c|c|}
\hline E. junceus & $5810^{*}$ \\
\hline E. sabulosus & $10 ”$ \\
\hline E. triticoides & $10^{*}$ \\
\hline E. sibiricus & 10 \\
\hline E. virginicus & $\begin{array}{llllll}3 & 5^{*} & 6 & 7 & 8 & 10^{*}\end{array}$ \\
\hline Eragrostis abyssinica & $710^{*}$ \\
\hline E. chloromelas & 8 \\
\hline E. curvula & $\begin{array}{lllllll}3 & 5 & 6 & 7 & 8 & 1 & 0\end{array}$ \\
\hline $\begin{array}{l}\text { E. lehmanniana } \\
\text { E. plana }\end{array}$ & $\begin{array}{ll}3 & 5 \\
3 & 8 \\
8 *\end{array}$ \\
\hline E. superba & $8^{\prime \prime} \quad 8^{n}$ \\
\hline E. trichodes & $3 * 8$ \\
\hline $\begin{array}{l}\text { Eriochloa annulata } \\
\text { Eustachys paspaloides }\end{array}$ & $\begin{array}{l}9 \text { (may not have been sown) } \\
57^{*} 10^{\prime \prime}\end{array}$ \\
\hline Festuca arenaria & \\
\hline F. arundinacea & $\begin{array}{llllllll}4 & 5 & 6 & 7 & 8 & 9 & 10 & 12\end{array}$ \\
\hline F. dumetorum & 2 \\
\hline F. duriuscula & 2 \\
\hline F. elatior & 13712 \\
\hline F. elatior var. alta & 7 \\
\hline F. heterophylia & 2 ' \\
\hline F. idahoensis & $35^{\prime} \quad 11$ \\
\hline F. longifolia & 2 \\
\hline F. maierei & $\begin{array}{lllll}3 & 5 & 7 & 10 & 12\end{array}$ \\
\hline F. matthewsii & \\
\hline F. novae zelandiae & 4578 \\
\hline F. ovina & $235^{*}$ \\
\hline F. ovina var. duriuscula & 28 \\
\hline F. pratensis & 45 \\
\hline F. rubra & 12345610 \\
\hline F. rubra var. fallax & 28 \\
\hline F. rubra var. genuina & 8 \\
\hline$F$. tenuijolia & 5 \\
\hline Hyparrihenia hirta & $58^{*} 10^{*}$ \\
\hline Hilaria jamesii & $5 *$ \\
\hline H. belangeri & $5^{*}$ \\
\hline Holcus lanntus & 14569 \\
\hline Hordeum bulbosum & 8 \\
\hline Ischaemum glaucostachyum & 9 (may not have been sown) \\
\hline Leptochloa dubia & $2^{*}$ \\
\hline Lolium multiflorum & 4512 \\
\hline L. perenne & $\begin{array}{llllll}14 & 5 & 8 & 9 & 10 & 12\end{array}$ \\
\hline N otodanthonia racemosa & \\
\hline N. thomsoni & 410 \\
\hline N. setifolia & 4 \\
\hline Oryzopsis hymenoides & 11 \\
\hline 0 . miliacea & 811 \\
\hline O. sfiparyropsis & 11 \\
\hline Panicum antidotale & $5^{*} 8$ \\
\hline P. bulbosum & $2^{*}$ \\
\hline P. laevifolium & 9 (may not have been sown) \\
\hline $\begin{array}{l}\text { P. maximum } \\
\text { P. oblusum }\end{array}$ & $\begin{array}{lll}5 * & 9 & 10^{*}\end{array}$ \\
\hline P. oblusum & \\
\hline
\end{tabular}




\begin{tabular}{|c|c|}
\hline P. plenum & 2 \\
\hline P. virgatum & $3^{\prime \prime} 5^{* *} 7$ \\
\hline Paspalum simplex & $5610^{\prime}$ \\
\hline Paspalidium retiglume & $5 *$ \\
\hline Pennisetum cinroides & 9 (may not have been sown) \\
\hline Phalaris aquatica & 8 \\
\hline $\begin{array}{l}\text { I'. arundinacea } \\
\text { P. canariensis }\end{array}$ & 48 \\
\hline P. coerulescens & 4811 \\
\hline P. commutata & 2 \\
\hline P. tuberosa & $\begin{array}{llllll}4 & 5 & 6 & 8 & 10 & 12\end{array}$ \\
\hline P. tuberosa var. hirtiglumis & 11 \\
\hline P. tuberosa var. stenoptera & 811 \\
\hline Phleum nodosum & 4 \\
\hline P. pratense & 45712 \\
\hline Poa ampla & $35 \div 781011$ \\
\hline P. bulbosa & \\
\hline P. caespitosa & 4568 \\
\hline P. colensoi & 245 \\
\hline P. compressa & 3 \\
\hline P. pratensis & 1245678910 \\
\hline$P$. scabrella & 11 \\
\hline P. secundn & $3^{*}$ \\
\hline P. trivialis & $\mathbf{5}^{\prime}$ \\
\hline Puccinellia species & 5 \\
\hline Secale cereale & 3 \\
\hline Setaria glauca & 9 (may not have been sown) \\
\hline S. woodii & $57^{\prime \prime} 10^{*}$ \\
\hline Sporobolus airoides & $3^{\prime}$ \\
\hline S. cryptandrus & $23^{*} 5^{*} 10^{\prime}$ \\
\hline$S$, fimbriatus & $8^{*}$ \\
\hline S. ftexuosus & $2^{*}$ \\
\hline S. wrightii & $2 *$ \\
\hline S. species & $6 * 7$ \\
\hline Stipa viridula & $310^{*}$ \\
\hline Themeda triandra & $5^{*}$ \\
\hline Tricholaena rosea & 2 \\
\hline Triodia exigua & 7 \\
\hline T. nuda & 2 \\
\hline Trisetum antarcticum & 8 \\
\hline T. kurizii & 7 \\
\hline Urochloa pullulans & $57^{\prime \prime} 10^{*}$ \\
\hline Vulpia dertonensis & 410 \\
\hline
\end{tabular}

